\title{
Lactococcus lactis subsp lactis
}

National Cancer Institute

\section{Source}

National Cancer Institute. Lactococcus lactis subsp lactis. NCI Thesaurus. Code C123497.

A species of Gram positive, cocci shaped, lactic acid bacteria assigned to the phylum Firmicutes. It is used in the manufacturing of cultured milk products and differs from Lactococcus lactis subsp. cremoris by being more hardy to salt, $\mathrm{pH}$, and high temperatures. 